Bangladesh J. PI. Breed. Genet, 24(1): 01-06

\title{
COMBINING ABILITY FOR YIELD AND YIELD CONTRIBUTING CHARACTERS IN KENAF (Hibiscus cannabinus L.)
}

\author{
M. G. Mostofa, L. Rahman ${ }^{1}$ and M. M. Hussain \\ Genetic Resources and Seed Division \\ Bangladesh Jute Research Institute \\ Manik Mia Avenue, Dhaka 1207, Bangladesh
}

\begin{abstract}
Combining ability in $6 \times 6$ half diallel crosses were estimated for yield and yield contributing characters in kenaf (Hibiscus cannabinus L.). Combining ability analysis revealed that mean square due to general combining ability (GCA) and specific combining ability (SCA) were significant for all the characters studied suggesting the presence of both additive and non-additive gene action for the inheritance of the concerned characters. The magnitude of GCA variance was considerably higher than that of SCA variance for days to $1^{\text {st }}$ flowering, fibre weight per plant and 1000-seed weight indicating the importance of additive gene action for these traits. The other characters were preponderantly controlled by non-additive gene action. Ranking of parents on GCA performance indicated that parent $\mathrm{P}_{6}$ (Acc.2731) was the best general combiner for fibre yield and yield attributes. On the other hand, parents $\mathrm{P}_{2}$ (Acc.4197) and $\mathrm{P}_{3}$ (Acc.2922) were found to be the best for seed related traits. On SCA performance, the crosses $\mathrm{P}_{3} \times \mathrm{P}_{5}, \mathrm{P}_{1} \times \mathrm{P}_{6}, \mathrm{P}_{3} \times \mathrm{P}_{6}$ and $\mathrm{P}_{4}$ $x P_{5}$ were found to be the best for fibre related traits, while the best specific crosses for seed related traits were $\mathrm{P}_{2} \times \mathrm{P}_{3}$ and $\mathrm{P}_{2} \times \mathrm{P}_{4}$. For the development of high fibre or seed yielding kenaf varieties, either pedigree selection method or recurrent breeding is suggested depending on the genetic behavior of the trait.
\end{abstract}

Key words: Kenaf (Hibiscus cannabinus L.), gca, sca and fibre yield

\section{INTRODUCTION}

Kenaf with jute and roselle are the second most important bast fibre crops next to cotton (IJSG, 2004). It is close relative to cotton and okra. Currently, it is growing with popularity in many countries of the world like India, China, Thailand and Vietnam (FAO, 2003) because of its high biological efficiency and wide ecological adaptability (Liu, 2003). It is the major alternative to trees for the production of paper and other products in USA, Australia, China and Japan (Clark, 1962; Kano, 1997 and Liu, 2000). In Bangladesh, it covers an area of 40 thousand hectare of land with 80-90 thousand tons of fibre production per annum (average yield 2.0-2.5 tons/ha) (BJRI, 2005). It has the potential for a variety of uses from rope and twine to animal litter and bedding, rugs to livestock feed, bags to paper. Combining ability is the ability of a parent to produce inferior or superior combinations in one or series of crosses (Chaudhary, 1982). Many commercial cultivars, besides their high

\footnotetext{
${ }^{1}$ Former Professor, Department of Genetics and Plant Breeding, Bangladesh Agricultural University, Mymensingh 2202, Bangladesh.
} 
agronomic performances, perform poorly in the $F_{1}$ generation, due to genetic hindrances in diverse cross combinations. Consequently, crossing in a diallel fashion is the only specific and effective technique for the measurement, identification and selection of superior genotypes (Mohammad, 2003). Knowledge of combining ability is, therefore, important in selecting suitable parents for hybridization, proper understanding of inheritance of quantitative traits and also in identifying the promising crosses for future use in breeding program. Very little works has however, been done to understand the nature of gene effects and the inheritance of yield and yield components in kenaf under Bangladesh condition. The present investigation is an attempt to know the hybrid performance of the crosses involving six selected promising lines.

\section{MATERIALS AND METHODS}

The parental materials (six parents) were selected on the basis of morpho-molecular characterization of 25 kenaf genotypes (Table 1). The parents were crossed in all possible combinations excluding reciprocals during October to November, 2008 at green house premises of Bangladesh Jute Research Institute (BJRI), Dhaka to generate $\mathrm{F}_{1} \mathrm{~s}$.

Table 1. Origin and salient features of six selected kenaf genotypes used as parents for diallel cross

\begin{tabular}{c|c|c|c|l}
\hline $\begin{array}{c}\text { Sl. } \\
\text { No. }\end{array}$ & $\begin{array}{c}\text { Genotype/ } \\
\text { Variety }\end{array}$ & Origin & $\begin{array}{c}\text { Days to } 1^{\text {st }} \\
\text { flowering }\end{array}$ & \multicolumn{1}{c}{ Salient features } \\
\hline $\mathrm{P}_{1}$ & CPI-72126 & Australia & $170-190$ & $\begin{array}{l}\text { Plant green, high biomass producing and quick } \\
\text { growing, late maturing, suitable for round the } \\
\text { year sowing. }\end{array}$ \\
$\mathrm{P}_{2}$ & Acc. 4197 & Kenya & $170-190$ & $\begin{array}{l}\text { Plant green, medium seed size, late maturing, } \\
\text { spiral borer susceptible. }\end{array}$ \\
$\mathrm{P}_{3}$ & Acc. 2922 & Netherlands & $90-100$ & $\begin{array}{l}\text { Purple stem, less photosensitive, early maturing } \\
\text { and day neutral, more or less tolerant to spiral } \\
\text { borer. } \\
\text { Plant green, very early maturing but less biomass, } \\
\text { spiral borer susceptible. }\end{array}$ \\
$\mathrm{P}_{4}$ & Acc. 5030 & Pakistan & $70-90$ & $\begin{array}{l}\text { Purplish stem, drought tolerance, late type, less } \\
\text { susceptible to spiral borer. }\end{array}$ \\
$\mathrm{P}_{5}$ & Acc. 4659 & Australia & $190-200$ & $\begin{array}{l}\text { Plant full green, late maturing, high biomass } \\
\text { producing, stem less spine, flowers completely } \\
\text { cream colour. }\end{array}$ \\
$\mathrm{P}_{6}$ & Acc. 2731 & Bangladesh & $175-195$ \\
\hline
\end{tabular}

Seeds of 21 entries including six parents and $15 \mathrm{~F}_{1}$ s were grown on $5^{\text {th }}$ April, 2009 at BJRI in a randomize block design with three replications. Each plot consisted of three rows of $1 \mathrm{~m}$ length with spacing of $30 \mathrm{~cm}$ between rows and $8-10 \mathrm{~cm}$ between plants. Five plants were randomly selected from each entry over replication for recording data on days to $1^{\text {st }}$ flowering, plant height $(\mathrm{m})$, stem-mid diameter $(\mathrm{mm})$, green bark thickness $(\mathrm{mm})$, fresh weight per plant $(\mathrm{g})$, fibre weight per plant $(\mathrm{g})$, stick weight per plant $(\mathrm{g})$, number of fruits per plant, number of seeds per fruit and 1000-seed weight (g). Analysis of combining ability was done according to Griffing's (1956) method-2, model-1. 


\section{RESULTS AND DISCUSSION}

Analysis of variance for combining ability (Table 2) showed highly significant mean squares due to GCA and SCA indicating both additive and non-additive gene actions were involved in the inheritance of studied traits. This result agreed with the findings of Sobhan (1993) in Hibiscus sabdariffa L.

Table 2. Analysis of variance for combining ability in kenaf

\begin{tabular}{c|c|c|c|c|c|c}
\hline $\begin{array}{l}\text { Sources of } \\
\text { variation }\end{array}$ & df & $\begin{array}{c}\text { Days to 1 } \\
\text { flowering }\end{array}$ & $\begin{array}{c}\text { Plant height } \\
(\mathrm{m})\end{array}$ & $\begin{array}{c}\text { Stem mid } \\
\text { diameter }(\mathrm{mm})\end{array}$ & $\begin{array}{c}\text { Green bark } \\
\text { thickness }(\mathrm{mm})\end{array}$ & $\begin{array}{c}\text { Fresh weight } \\
\text { /plant }(\mathrm{g})\end{array}$ \\
\hline $\mathrm{GCA}$ & 5 & $4191.53^{* *}$ & $0.19^{* *}$ & $8.03^{* *}$ & $1.00^{* *}$ & $17062.46^{* *}$ \\
$\mathrm{SCA}$ & 15 & $367.95^{* *}$ & $0.04^{* *}$ & $1.67^{* *}$ & $0.30^{* *}$ & $3395.27^{* *}$ \\
Error & 40 & 8.90 & 0.002 & 0.10 & 0.02 & 211.77 \\
\hline Components & \multicolumn{5}{c}{} \\
\hline$\sigma^{2} \mathrm{~g}$ & 477.95 & 0.02 & 0.80 & 0.09 & 1708.40 \\
$\sigma^{2} \mathrm{~s}$ & 359.05 & 0.04 & 1.57 & 0.28 & 3183.50 \\
$\sigma^{2} \mathrm{~g}: \sigma^{2} \mathrm{~s}$ & 1.33 & 0.50 & 0.51 & 0.32 & 0.54 \\
\hline
\end{tabular}

Cont'd. (Table 2)

\begin{tabular}{c|c|c|c|c|c|c}
\hline $\begin{array}{l}\text { Sources of } \\
\text { variation }\end{array}$ & $\mathrm{df}$ & $\begin{array}{l}\text { Fibre weight } \\
\text { /plant (g) }\end{array}$ & $\begin{array}{c}\text { Stick weight } \\
\text { /plant (g) }\end{array}$ & $\begin{array}{c}\text { Number of } \\
\text { fruits/plant }\end{array}$ & $\begin{array}{c}\text { Number of } \\
\text { seeds/fruit }\end{array}$ & $\begin{array}{c}1000 \text {-seed } \\
\text { weight }(\mathrm{g})\end{array}$ \\
\hline GCA & 5 & $170.38^{* *}$ & $505.51^{* *}$ & $38.00^{* *}$ & $26.10^{* *}$ & $20.32^{* *}$ \\
SCA & 15 & $15.09^{* *}$ & $106.12^{* *}$ & $11.41^{* *}$ & $6.29^{* *}$ & $1.55^{* *}$ \\
Error & 40 & 1.12 & 8.27 & 1.27 & 1.10 & 0.07 \\
\hline Components & \multicolumn{5}{c}{2.35} \\
\hline$\sigma^{2} \mathrm{~g}$ & 19.41 & 49.92 & 3.32 & 2.48 & 1.48 \\
$\sigma^{2} \mathrm{~s}$ & 13.97 & 97.85 & 10.14 & 5.19 & 1.59 \\
$\sigma^{2} \mathrm{~g}: \sigma^{2} \mathrm{~s}$ & 1.39 & 0.51 & 0.33 & 0.48 & \\
\hline
\end{tabular}

$* \& *$, significant at $5 \%$ and $1 \%$ level of significance, respectively

The ratio of GCA and SCA variances were more than unity for days to $1^{\text {st }}$ flowering, fibre weight per plant and 1000-seed weight which indicated the predominance of additive gene effects in the expression of the characters. Estimated GCA/SCA was less than unity for rest of the characters which revealed the predominance of non-additive gene action for those characters. These results have close agreement with the findings of Gupta and Singh (1986) in roselle and Qi et al. (2005) in kenaf but disagreed with the findings of Heliyanto et al. (1998) in kenaf. Mukewar et al. (1997) observed the predominance of additive gene action for seed yield per plant and number of capsules per plant in kenaf. Pace et al. (1998) reported that additive gene action was more important for yield components viz. plant height, fresh and dry weight of bark and usable stick in kenaf. However, when compared in terms of average effects (components), SCA effects were greater than those of GCA, indicating the importance of non-additive gene action in determining expression of yield components.

\section{GCA effects of the parents}

The estimates of GCA effects (Table 3) indicated that the parent $\mathrm{P}_{3}$ and $\mathrm{P}_{4}$ were good general combiner for early maturity as they had significant negative GCA effects for 
days to $1^{\text {st }}$ flowering. A positive GCA effect is desired for plant height to get a taller stature combination. The parent $\mathrm{P}_{6}$ exhibited the highest and significant positive GCA effects which indicated that the parent was the best general combiner for plant height. It was also the best for fibre weight per plant and yield related other traits viz. stem-mid diameter, green bark thickness, fresh weight per plant and stick weight per plant. This was followed by $\mathrm{P}_{2}$ and $\mathrm{P}_{1}$ for most of the cases. Parents with negative GCA effects for 1000-seed weight considered as the best general combiner for smaller seed size. Parents $\mathrm{P}_{3}$ and $\mathrm{P}_{2}$ were the best general combiners for 1000-seed weight and also for higher number of fruits per plant (having higher GCA values). Similarly the parents $\mathrm{P}_{2}$ and $\mathrm{P}_{5}$ might be used for maximum number of seeds per fruit as they showed high estimate of GCA effects for this trait. The overall study of GCA effects of parents suggested that the parent $\mathrm{P}_{6}$ was the best general combiner for fibre yield and yield related all traits, while parents $\mathrm{P}_{2}$ and $\mathrm{P}_{3}$ were the best general combiners for seed related characters. Therefore, they could be used as parents for yield improving program in kenaf.

Table 3. Estimates of general combining ability (GCA) effect for 10 morphological characters of kenaf

\begin{tabular}{c|c|c|c|c|c}
\hline \multirow{2}{*}{ Parents } & \multicolumn{5}{c}{ GCA } \\
\cline { 2 - 6 } & $\begin{array}{c}\text { Days to } 1^{\text {st }} \\
\text { flowering }\end{array}$ & $\begin{array}{c}\text { Plant } \\
\text { height }(\mathrm{m})\end{array}$ & $\begin{array}{c}\text { Stem mid- } \\
\text { diameter }(\mathrm{mm})\end{array}$ & $\begin{array}{c}\text { Green bark } \\
\text { thickness }(\mathrm{mm})\end{array}$ & $\begin{array}{c}\text { fresh weight } \\
\text { /plant }(\mathrm{g})\end{array}$ \\
\hline $\mathrm{P}_{1}$ & $16.96^{* *}$ & $0.16^{* *}$ & $0.47^{* *}$ & 0.02 & $16.89^{* *}$ \\
$\mathrm{P}_{2}$ & $3.96^{* *}$ & $0.06^{* *}$ & $0.68^{* *}$ & $0.22^{* *}$ & $21.01^{* * *}$ \\
$\mathrm{P}_{3}$ & $-30.29^{* *}$ & $-0.06^{* *}$ & $-1.14^{* *}$ & $-0.45^{* *}$ & $-43.82^{* *}$ \\
$\mathrm{P}_{4}$ & $-26.92^{* *}$ & $-0.18^{* *}$ & $-1.10^{* *}$ & $-0.41^{* *}$ & $-54.86^{* *}$ \\
$\mathrm{P}_{5}$ & $20.96^{* *}$ & $-0.15^{* *}$ & $-0.25^{* *}$ & $0.22^{* *}$ & -9.36 \\
$\mathrm{P}_{6}$ & $15.33^{* *}$ & $0.17^{* *}$ & $1.34^{* *}$ & $0.40^{* *}$ & $70.14^{* *}$ \\
$\mathrm{SE}\left(\mathrm{g}_{\mathrm{i}}\right)$ & 0.96 & 0.0003 & 0.10 & 0.05 & 4.70 \\
$\mathrm{SE}\left(\mathrm{g}_{\mathrm{i}}-\mathrm{g}_{\mathrm{j}}\right)$ & 1.49 & 0.02 & 0.16 & 0.07 & 7.28 \\
\hline
\end{tabular}

Cont'd. (Table 3)

\begin{tabular}{c|c|c|c|c|c}
\hline \multirow{2}{*}{ Parents } & \multicolumn{5}{|c}{ GCA } \\
\cline { 2 - 6 } & $\begin{array}{c}\text { Fibre weight } \\
\text { /plant }(\mathrm{g})\end{array}$ & $\begin{array}{c}\text { Stick weight } \\
\text { /plant }(\mathrm{g})\end{array}$ & $\begin{array}{c}\text { Number of } \\
\text { fruits/plant }\end{array}$ & $\begin{array}{c}\text { Number of } \\
\text { seeds/fruit }\end{array}$ & $\begin{array}{c}1000 \text {-seed } \\
\text { weight }(\mathrm{g})\end{array}$ \\
\hline $\mathrm{P}_{1}$ & $1.64^{* *}$ & $3.04^{* *}$ & $-2.75^{* *}$ & $-1.35^{* *}$ & $0.62^{* * *}$ \\
$\mathrm{P}_{2}$ & $0.95^{* *}$ & $4.63^{* *}$ & $1.88^{* *}$ & $2.61^{* *}$ & $-1.12^{* *}$ \\
$\mathrm{P}_{3}$ & $-3.97^{* *}$ & $-5.16^{* *}$ & $2.50^{* *}$ & 0.28 & $-1.62^{* *}$ \\
$\mathrm{P}_{4}$ & $-5.68^{* *}$ & $-9.78^{* *}$ & $1.38^{* *}$ & $-2.47^{* *}$ & 0.13 \\
$\mathrm{P}_{5}$ & -0.34 & $-4.64^{* *}$ & $-1.63^{* *}$ & $1.19^{* *}$ & $-0.80^{* *}$ \\
$\mathrm{P}_{6}$ & $7.40^{* *}$ & $11.89^{* *}$ & $-1.38^{* *}$ & -0.26 & $2.79^{* *}$ \\
$\mathrm{SE}\left(\mathrm{g}_{\mathrm{i}}\right)$ & 0.34 & 0.93 & 0.36 & 0.34 & 0.09 \\
$\mathrm{SE}\left(\mathrm{g}_{\mathrm{i}}-\mathrm{g}_{\mathrm{j}}\right)$ & 0.53 & 1.44 & 0.56 & 0.53 & 0.13 \\
\hline
\end{tabular}

$\& * *$, significant at $5 \%$ and $1 \%$ level of significance, respectively

\section{SCA effects of the crosses}

The results of SCA effects of different characters are presented in Table 4. The cross $\mathrm{P}_{3} \times \mathrm{P}_{5}$ showed significant positive SCA effects for fibre weight per plant. This was followed by $\mathrm{P}_{1} \times \mathrm{P}_{6}$ and $\mathrm{P}_{3} \times \mathrm{P}_{6}$. 
Table 4: Estimates of specific combining ability (SCA) effects for 10 different morphological characters of kenaf

\begin{tabular}{|c|c|c|c|c|c|c|c|c|c|c|}
\hline \multirow[b]{2}{*}{ Crosses } & \multicolumn{10}{|c|}{ SCA } \\
\hline & $\begin{array}{l}\text { Days to } 1^{\text {st }} \\
\text { flowering }\end{array}$ & $\begin{array}{l}\text { Plant height } \\
\text { (m) }\end{array}$ & $\begin{array}{l}\text { Stem mid- } \\
\text { diameter } \\
(\mathrm{mm})\end{array}$ & $\begin{array}{l}\text { Green bark } \\
\text { thickness } \\
(\mathrm{mm})\end{array}$ & $\begin{array}{l}\text { Fresh weight } \\
\text { /plant (g) }\end{array}$ & $\begin{array}{l}\text { Fibre weight } \\
\text { /plant (g) }\end{array}$ & $\begin{array}{l}\text { Stick weight } \\
\text { / plant (g) }\end{array}$ & $\begin{array}{l}\text { Number of } \\
\text { fruits/plant }\end{array}$ & $\begin{array}{l}\text { Number of } \\
\text { seeds/fruit }\end{array}$ & $\begin{array}{l}\text { 1000-seed } \\
\text { weight }(\mathrm{g})\end{array}$ \\
\hline $\mathrm{P}_{1} \times \mathrm{P}_{2}$ & 5.04 & $-0.09 * *$ & 0.10 & 0.04 & -14.08 & -0.42 & -1.60 & -0.55 & $-2.81 * *$ & $-1.08 * *$ \\
\hline $\mathrm{P}_{1} \times \mathrm{P}_{3}$ & $17.29 *$ & $0.03 * *$ & 0.35 & $-0.32 *$ & 0.43 & -0.34 & 1.49 & $-2.18^{*}$ & 0.53 & -0.08 \\
\hline $\mathrm{P}_{1} \times \mathrm{P}_{4}$ & $16.91 *$ & $-0.08 * *$ & -0.36 & $-0.43 * *$ & $-26.20 *$ & -1.33 & -5.01 & -0.05 & -0.38 & $2.22 * *$ \\
\hline $\mathrm{P}_{1} \times \mathrm{P}_{5}$ & -7.96 & $-0.01 * *$ & 0.47 & $0.34 * *$ & -9.70 & 0.70 & -1.13 & $-1.05^{*}$ & $-2.72 * *$ & 0.09 \\
\hline $\mathrm{P}_{1} \times \mathrm{P}_{6}$ & -1.34 & $0.10 * *$ & $0.65 *$ & $1.16 * *$ & $70.80 * *$ & $5.69 * *$ & $15.25^{* *}$ & -0.30 & 1.07 & $-0.56^{*}$ \\
\hline $\mathrm{P}_{2} \times \mathrm{P}_{3}$ & $-33.71 * *$ & $0.29 * *$ & 0.55 & $-0.72 * *$ & 18.96 & 1.79 & $6.10 *$ & $7.20 * *$ & $2.43^{*}$ & 0.32 \\
\hline $\mathrm{P}_{2} \times \mathrm{P}_{4}$ & $19.91 * *$ & $0.07 * *$ & -0.12 & 0.24 & -19.33 & -1.54 & -3.82 & $3.32 * *$ & $2.66 * *$ & $-2.00 * *$ \\
\hline $\mathrm{P}_{2} \times \mathrm{P}_{5}$ & 1.04 & $0.02 * *$ & 0.07 & 0.21 & 16.84 & $2.12 *$ & -0.53 & 0.32 & 0.35 & $0.59 *$ \\
\hline $\mathrm{P}_{2} \times \mathrm{P}_{6}$ & -10.34 & $-0.01 * *$ & -0.12 & 0.16 & 5.34 & -0.95 & 2.25 & 0.07 & $2.78 * *$ & -0.42 \\
\hline $\mathrm{P}_{3} \times \mathrm{P}_{4}$ & $-22.84 * *$ & $-0.09 * *$ & -0.11 & 0.24 & -14.16 & -1.05 & -3.16 & $4.70 * *$ & $3.65 * *$ & $-1.03 * *$ \\
\hline $\mathrm{P}_{3} \times \mathrm{P}_{5}$ & 11.29 & $0.46^{* *}$ & $2.25 * *$ & $0.58 * *$ & $117.34 * *$ & $6.61 * *$ & $20.33 * *$ & 0.70 & $3.99 * *$ & 0.44 \\
\hline $\mathrm{P}_{3} \times \mathrm{P}_{6}$ & $16.91^{*}$ & $0.02 * *$ & $1.99 * *$ & $-0.27 *$ & $75.18 * *$ & $4.90 * *$ & $11.20^{* *}$ & 0.45 & 0.12 & -0.19 \\
\hline $\mathrm{P}_{4} \times \mathrm{P}_{5}$ & $21.91 * *$ & $0.01 * *$ & $1.74 * *$ & $0.68 * *$ & $64.05^{* *}$ & $4.52 * *$ & $10.45^{* *}$ & -0.18 & $-2.27 *$ & $0.58 *$ \\
\hline $\mathrm{P}_{4} \times \mathrm{P}_{6}$ & $20.54 * *$ & $0.03 * *$ & $0.08 \mathrm{~ns}$ & $-0.30^{*}$ & -16.12 & -1.45 & -1.78 & $-3.43 * *$ & $-3.14 * *$ & $2.06 * *$ \\
\hline $\mathrm{P}_{5} \times \mathrm{P}_{6}$ & -6.34 & $-0.13^{* *}$ & $-0.90 * *$ & $-0.69 * *$ & $-46.28 * *$ & $-2.19^{*}$ & $-9.32 * *$ & 0.57 & -0.80 & $-1.84 * *$ \\
\hline $\mathrm{SE}\left(\mathrm{s}_{\mathrm{ij}}\right)$ & 2.64 & 0.001 & 0.28 & 0.13 & 12.90 & 0.94 & 2.55 & 1.00 & 0.93 & 0.24 \\
\hline $\mathrm{SE}\left(\mathrm{s}_{\mathrm{ij}} \mathrm{s}^{\mathrm{i}} \mathrm{ik}\right)$ & 3.95 & 0.06 & 0.42 & 0.19 & 19.25 & 1.40 & 3.80 & 1.49 & 1.39 & 0.35 \\
\hline $\operatorname{SE}\left(\mathrm{s}_{\mathrm{ij}}-\mathrm{s}_{\mathrm{kl}}\right)$ & 3.65 & 0.058 & 0.39 & 0.17 & 17.82 & 1.30 & 3.52 & 1.38 & 1.29 & 0.33 \\
\hline
\end{tabular}

$* \& * *$, significant at $5 \%$ and $1 \%$ level of significance, respectively 
These three crosses showed also significant and positive SCA effects for fibre related all traits viz. plant height, stem-mid diameter, fresh weight per plant and stick weight per plant. Generally crosses involving high $\mathrm{x}$ low general combiner for yield components perform better. Parents $\mathrm{P}_{3}$ and $\mathrm{P}_{5}$ were poor general combiner and parents $\mathrm{P}_{6}$ and $\mathrm{P}_{1}$ were good general combiner for fibre weight per plant and yield related other traits. Highly significant SCA value for fibre weight per plant was also observed in the cross $\mathrm{P}_{4} \times \mathrm{P}_{5}$, in which both parents were poor combiner for fibre yield and yield related other traits. Crosses with high $\mathrm{x}$ low and low $\mathrm{x}$ low general combiner exhibiting high SCA effects were explained by Jinks (1956) as due to over-dominance and epistasis. High performance by crossing involving two parents with low $\mathrm{x}$ low general combiner has been explained as due to complementary gene action (Mohndiratta, 1968). The crosses $\mathrm{P}_{2} \times \mathrm{P}_{3}$ and $\mathrm{P}_{3} \times \mathrm{P}_{4}$ showed maximum SCA effects for earliness in flowering and number of fruits per plant. For number of seeds per fruit, SCA effects were significant in the crosses $\mathrm{P}_{3} \times \mathrm{P}_{5}, \mathrm{P}_{3} \times \mathrm{P}_{4}, \mathrm{P}_{2} \times \mathrm{P}_{6}$ and $\mathrm{P}_{2} \times \mathrm{P}_{4}$. Significant negative SCA effects for 1000-seed weight which is expected for smaller seed size were found in the crosses $\mathrm{P}_{2}$ x $\mathrm{P}_{4}, \mathrm{P}_{5} \times \mathrm{P}_{6}, \mathrm{P}_{1} \times \mathrm{P}_{2}$ and $\mathrm{P}_{3} \times \mathrm{P}_{4}$. The above results indicated that the crosses $\mathrm{P}_{3} \times \mathrm{P}_{5}, \mathrm{P}_{1} \times \mathrm{P}_{6}, \mathrm{P}_{3} \times \mathrm{P}_{6}$ and $\mathrm{P}_{4} \times \mathrm{P}_{5}$ had significant $\mathrm{SCA}$ effects for fibre weight per plant associated with some yield contributing characters involving low $\mathrm{x}$ low, high $\mathrm{x}$ high and high $\mathrm{x}$ low GCA parents, while crosses $\mathrm{P}_{2} \times \mathrm{P}_{3}$ and $\mathrm{P}_{2} \times \mathrm{P}_{4}$ were found promising for earliness, smaller seed size and seed related other traits. Therefore, the SCA effects of these crosses could effectively be exploited in hybrid breeding program in kenaf.

\section{REFERENCES}

BJRI. 2005. Jute and kenaf seed production, storage and distribution activities. Bangladesh Jute Research Institute. Reports July, 2004 to June, 2005. pp. 16-17.

Chaudhary, R. C. 1982. Introduction to plant breeding. Oxford and IBH Publishing Co. Pvt. Ltd. New Delhi

Clark, T. F. 1962. A research of new fiber crops, Part-V. Pulping study on kenaf. Tappi J. 45(10): 780-786.

FAO. 2003. The production and consumption of kenaf in China. Consultation on natural fibers. Food and Agriculture Organization. ESC-Fibers Consultation No: 03/6

Griffing, B. 1956. Concept of general and specific combining ability in relation to diallel crossing system. Aust. J. Bio. Sci. 6(4): 463-493.

Gupta, D and D. P. Singh. 1986. Line x tester analysis for combining ability in roselle (Hibiscus sabdariffa L.). Phytobreedon. 2(1): 35-41.

Heliyanto, B., M. Hossain and S. L. Basak. 1998. Genetic evaluation of several kenaf (Hibiscus cannabinus) germplasm through diallel crossing. Indonesian J. Crop Sci. 13(1): 15-22.

IJSG. 2004. The International Jute Study Group. http://www.jute.org

Jinks, J. L. 1956. The $\mathrm{F}_{2}$ and backcross generations from a set of diallel crosses. Hered. 10: 1-30.

Kano, T. 1997. Development and prospect of kenaf board. Reference No. 47 of the kenaf society of Kochi and economic reports of Ehime. Nov.10, 1997 (in Japanese).

Liu, A. M. 2000. World production and potential utilization of jute, kenaf and allied fibers. In: Proceedings of the 2000 international kenaf symposium. Hiroshima, Japan. Pp. 30-35.

Liu, A. M. 2003. Making pulp and paper from kenaf. http://www.chinaconsultinginc.com/ paperpulp.htm

Mohammad, S. M. 2003. Diallel analysis for estimating combining ability of quantitatively inherited traits in upland cotton. Asian Journal of Plant Sciences. 2(11): 853-857.

Mohndiratta, P. D. 1968. General and specific combining ability studies and graphical analysis in wheat (Triticum aestivum L.). M. Sc. (Ag.) Thesis, Punjab Agric. Univ. Ludhiana, India.

Mukewar, A. M., J. S. Zope and P. S. Lahane. 1997. Combining ability analysis in kenaf (Hibiscus sabdariffa L.). Indian J. Genet. Pl. Breed. 57(2): 161-162.

Pace, S., I. Piscioneri and I. Settanni. 1998. Heterosis and combining ability in a half diallel cross of kenaf (Hibiscus cannabinus L.) in south Italy. Special issue. Selected papers from the Third European Symposium on Industrial Crops and Products, Reims, France, 22-24 April 1996. Part II. 1998. 7(2-3): 317-327.

Qi, J. M., Y. Y. Chen, R. Y. Zhou, L. H. Lin, K. J. Liang, J. M. Wu and P. P. Fang. 2005. Genetic effects and heterosis analysis for yield and quality traits in kenaf. Acta Agronomica Sinica. 31(40): 469-475.

Sobhan, M. A. 1993. Heritability of fibre, fruit and seed yields in Hibiscus sabdariffa. Ph. D. thesis, Department of Botany, University of Dhaka. pp. 101-201. 